\title{
Study on the ESP Teachers' Professional Stress and Development in Transformation during the CBI Teaching Reform
}

\author{
Yansong Feng \\ School of Foreign Languages \\ Xuzhou Institute of Technology \\ Xuzhou, Jiangsu, China 221008
}

\begin{abstract}
Many ESP courses are offered in the CBI teaching reform, which comply with the nation's strategy of cultivating multi-ability talents, and the reform is the definite direction of the college English teaching in China. However, the CBI reform is a great stress and challenge to those who need to transform from a college English teacher to an ESP teacher, as well as a great impetus to boost their professional development. In order to achieve a perfect transformation, the ESP teachers and their colleges can quicken and optimize their professional development in at least eight ways so that they will adapt to the new teaching mode.
\end{abstract}

Keywords-CBI; ESP; professional stress; professional development

\section{INTRODUCTION}

CBI teaching reform of universities brings new hope for the backward college English teaching, makes the college English teaching under the new situation have new development direction and target and meet the requirement of cultivating compound talents proposed by Outline of the National Medium and Long Term Educational Reform and Development Plan (2010-2012) (hereinafter referred to as the Outline. However, it also brings great stress and challenge for college English teachers to transform, because it directly influences the development of teachers in the future. This paper will discuss it.

\section{HISTORICAL BACKGROUND OF CBI REFORM}

With the development of college English reform, profound changes also occur in national requirements for college English teaching. For example, compared with Teaching Requirements of College English Course (Trial) in 2004, the official version revised in 2007 highlights the combination with professional learning. It clearly requires students "should be able to understand English lecture related to their major and grasp the main idea and seize the gist", "fluently and correctly have a dialogue or discuss ordinary or professional topics", "read out paper in international conference and professional

Some achievements of 2013 Jiangsu Province Higher Education Teaching Reform Research Subject "Research on Demonstration of Application of CBI in College English Teaching and Teaching Effects -Take art student in our School as the Research Object" (Subject number: 2013JSJG483) communication and discuss", "smoothly read comprehensive literature related to the major", "use English to write technical report and paper of their major". Meanwhile, "universities shall consider setting some cross-cultural communication contents in teaching to improve comprehensive quality of students". It indicates clear direction for the consequent college English teaching reform-English teaching should have instrumental and humanistic functions.

The Outline issued in 2010 proposes new requirements for higher education of our country, "optimize specialty, type and structure and promote intersection and integration of disciplines. Focus on expanding cultivation scale of applied, compound and skilled talents", "cultivate international talents with international view that thoroughly understand international rules and participate in international affairs and competition". Under these guiding principles, college English teaching in the new era is changing from test-orientated education to instrumental and humanistic teaching. The most representative is the establishment and popularization of ESP under CBI reform.

\section{COLLEGE ENGLISH REFORM BASED ON CBI TEACHING Mode ANd CURRENT SituATION OF RELATED RESEARCH}

\section{A. Application of CBI Teaching Mode in Reform}

The CBI (Content-based Instruction) is derived from 1965 , which builds language teaching based on subject teaching or theme teaching, combines language learning with subject knowledge learning to improve subject knowledge and cognitive competence of students as well as language level. The initiator Mohann proposes in Language and Content, "the separation of language and specialty makes language lose the function as a tool and the communication is not targeted and real because of it". He emphasizes the language, specialty and content are inseparable (Mohann, 1986). Krahnke clearly defines CBI as, "a teaching method of language acquisition in content or information teaching" (Krahnke, 1987). CBI teaching idea absorbs second language acquisition theory, cognitive learning theory, communicative approach theory and cooperative learning theory, focuses on subject knowledge, uses true language materials, learns new information and the curriculum provision meets the requirements of different 
learners, pays attention to improving subjective initiative and participation of students and integrates communicative approach, cooperation method, task method in teaching to adjust to different learning groups.

Compared with traditional language teaching, the marked feature of $\mathrm{CBI}$ embodies in the change from form-focused instruction to significance and function teaching, from phonics skill teaching to subject content teaching. CBI idea has been fully applied in college English course reform of our country. Universities open ESP, EAP or subject English, combines professional knowledge and language skills and "completely give up the only standard of language, use content as the basis of language selection and compilation" and fulfill the teaching idea of "centering on contents with language as assistant" (Cai Jigang, 2011). Besides, many scholars have supported it since the reform. For example, Lei Chunlin (2006), Yuan Pinghua (2010), Liu Runqing (2011), Sun Youzhong (2011) and Cai Jigang (2012) think ESP curriculum will be the development direction of college English teaching of our country and put forward their own opinions on CBI teaching mode. They predict with the deepening of reform and improvement of language competence of learners, CBI model will gradually become subject-oriented and professional until professional teaching using English totally replaces language teaching. In short, new college English reform should change from language skill to professional knowledge. ESP curriculum teaching under CBI teaching mode will be inevitable direction and result of college English reform.

\section{B. Current Situation of Research on College English Course Reform under CBI Model}

With deep popularization of college English ESP course reform supported by $\mathrm{CBI}$ idea, related researches are also increasingly rich. The author has retrieved the papers published in recent five years with "CBI" and "ESP" as the keywords on CNKI. In order to exclude papers with "CBI" and "ESP" as keywords in other industries, the author carries out the second retrieval in the results of them with the theme of "teaching" respectively and has got related data; and then use the theme of "teacher" to retrieve again in the results with keywords of "CBI" and "ESP". The statistical data are shown in Table I.

TABLE I. STATISTICAL TABLE OF DATA RETRIEVED FROM CNKI

\begin{tabular}{|l|l|l|l|l|}
\hline \multicolumn{1}{|c|}{ Year } & $\begin{array}{c}\text { CBI+ } \\
\text { teaching }\end{array}$ & $\begin{array}{c}\text { CBI+ } \\
\text { teacher }\end{array}$ & $\begin{array}{c}\text { ESP+ } \\
\text { teaching }\end{array}$ & $\begin{array}{c}\text { ESP+ } \\
\text { teacher }\end{array}$ \\
\hline 2014 & 123 & 24 & 324 & 72 \\
\hline 2013 & 103 & 27 & 306 & 86 \\
\hline 2012 & 78 & 21 & 268 & 81 \\
\hline 2011 & 54 & 12 & 198 & 57 \\
\hline 2010 & 32 & 8 & 141 & 26 \\
\hline
\end{tabular}

According to table 1, with the popularization of CBI idea and ESP curriculum, the research on application of them in teaching also increases by years. In recent five years, the number of research paper on application of CBI increases from 32 in 2010 to 123 in 2014; the number of research paper on ESP curriculum also increases from 141 in 2010 to 324 in 2014. There is no lack of core journals. The opinions of scholars such as Sun Youzhong (2011), Yang Daoyun (2012), Zhao Xiuyan (2014) and Cai Jigang (2014) are insightful and have big influence. It shows that in recent five years, an increasing number of universities have chosen content-based college English teaching reform and have met the new requirements of college English teaching and national medium and long term educational development plan.

However, we find a notable problem: among all the research papers with the keywords of CBI and ESP, there are fewer results with the theme of "teacher" than results with the theme of "teaching". It shows that people pay more attention to empirical research and applied research of reform and neglect the extremely important condition related to success or failure of the reform -the transformation from college English teachers to ESP teachers.

\section{OCCUPATIONAL STRESS OF ESP TEACHERS IN THE TRANSFORMATION PERIOD AND DOMINANT EXPRESSION}

Undoubtedly, CBI mode has higher demand for knowledge structure and teaching skills of foreign language teachers. It shows in table 1 that there are few researches on the situation of ESP teachers in the transformation period under CBI teaching reform, namely their psychological changes and occupational stress. Occupational stress of teachers refers to undesirable emotional experience of teachers occurred because the requirements of society on the teachers' profession exceed the ability level of teachers. Most teachers who get accustomed to EGP teaching cannot adapt to ESP curriculums in CBI reform immediately, which makes them less confident about the teaching ability. They are anxious and think they are incompetent.

Although there are few researches on occupational stress of ESP teachers in the transformation period, at present, some scholars begin to pay attention to it, such as Xia Yang. According to the investigation of Xia Yang (2012), in order to meet the need of ESP teaching, most teachers supplement professional knowledge through "reading specialized reference and literature". But they seldom get professional development through other ways, such as "professional training and organized professional activity", "discussion with colleagues in daily life" and "learning from experienced teachers". It shows most ESP teachers rely on personal effort to carry out professional development, which will bring them heavy occupational stress.

The author comes to the same conclusion according to the survey. Our school began to implement ESP course reform under CBI idea last year. Now it is still in the initial exploration stage. There are four courses including Business English. According to the requirements and plan of the school, next year the number of ESP curriculum will rise to more than ten. Although it is still in the initial stage, the author finds the huge transformation stress brought by the reform has begun to appear. It mainly shows in the following aspects:

\section{A. Lack Related Professional Knowledge, Difficult to Prepare Lessons}

Because of lacking necessary professional training and guidance at the beginning of the reform, many teachers 
teaching ESP curriculum do not have professional knowledge reserve, ending in the increase of difficulty in preparation of lessons and teaching. The results of the author's survey are the same as that of Xia Yang (2012). More than $80 \%$ of teachers think they make up for the inadequacy of professional knowledge by reading professional literature or using network to search for related contents. The short of professional knowledge is the primary element causing huge stress for ESP teachers in the transformation period. The stress is very difficult to relieve without training guidance and the help from experienced teachers. Meanwhile, the selected ESP textbooks are new. It is difficult to find out matched teaching materials. Teaching links such as outline formulation, compilation of teaching plan, courseware making and examination proposition also bring some stress for teachers.

\section{B. Lack Related Professional Teaching Theory and the Class Is Random}

The characteristics and rules of ESP teaching are different from that of the EGP teaching, because the CBI is to combine not only two subject contents but also language teachers and disciplinary teachers. It requires ESP teachers to skillfully master language teaching skills, know subject knowledge well and has the high sensitivity to take different teaching strategies for different students (Pawan \& Sietman, 2007). Because of poor preparation of ESP teaching theory and related teaching theories, short of efficient teaching links and knowledge expansion corresponding to ESP course and big randomness in class, some teachers tend to change ESP teaching into EGP. In this way, it diverges from the ultimate purpose of CBI reform. Therefore, except for professional knowledge, it is also one of the ways for teachers to relieve the stress through acquiring necessary ESP teaching theories.

\section{Lack Professional Practical Experience, Engage in Idle Theorizing}

Although professional knowledge can be made up for the moment through referring to the literature, college English teachers, no matter graduate or doctor, learn and research English language or literature and seldom learn professional English. It is congenitally deficient in the current ESP teaching; besides, for some specialties, necessary practical experience is also the prerequisite to answer ESP curriculum unhurriedly. For example, Business English will involve large number of business practices; another example, chapter in ESP curriculum of our school involves economics. Under the help of literature and reference, teachers can only have a smattering of knowledge and it is impossible for them to achieve mastery in short period of time. They repeat what the book says. Therefore, many ESP courses become formalistic. Students neither get professional knowledge and practice brought by professional teachers nor learn English skills.

The above problems make teachers get half the result with twice the effort. It brings huge stress and frustrated feelings for ESP teachers in the transformation and is very likely to damage self-confidence and enthusiasm of them in teaching. It is more worrying that the accumulation of professional knowledge and the improvement of interdisciplinary ability do not accomplish in an action.
Moreover, the scientific research stress brought by CBI reform cannot be ignored. With ESP curriculum is followed by researches on related fields such as classroom design, teaching efficiency, teaching evaluation, psychology of teachers and students. It will be great challenges for ESP teachers in the initial stage.

\section{The RoAd To Professional DeVElopMENT OF ESP TEACHERS In THE TRANSFORMATION PERIOD In CBI REFORM}

Challenges and opportunities are coexisting. Although CBI reform brings huge occupational stress for English teachers in the transformation period, if they adjust state of mind to actively face the challenge, the huge occupational stress will become powerful impetus and greatly promote professional development of teachers.

\section{A. Definition of Teachers' Professional Development}

The professional development of foreign teachers is affected by cognitive science, constructivism and ecological theory successively. It pays attention to the research on knowledge, professional standard and professional development mode of teachers. Different scholars have different opinions on teachers' professional development. For example, Zhu Xinzhuo thinks teachers' professional development refers to the process of professional growth of teachers on the basis of the improvement of professional qualities such as knowledge, skill and emotions. Zhu Yudong thinks teachers' professional development refers to the process that the professional quality of teachers improves as well as the process of continuous update, gradual progress and improvement of teachers' professional faith, knowledge, ability and emotion (quoted from Zhou Yueliang, 2008). On the whole, teachers' professional development can be understood as the process of dynamic development that teachers' internal professional structure and accomplishment (including professional psychology) update and improve continuously. It is the process of dynamic and continuous lifelong development of teachers with growth of teachers as the guidance, specialization as the purpose and the knowledge, skill, faith, attitude and emotion of teachers as the content.

\section{B. Analysis on Motivation of ESP Teachers' Professional Development}

Unquestionably, the huge occupational stress brought by CBI reform can change into impetus and great opportunity for ESP teachers' professional development. Just as Yang Daoyu says, teachers" professional development is "the result of interaction of external and internal forces. The external force is the macro curriculum structure and the internal force is the exchange need of teachers. The interaction of them drives the professional development of teachers" (Yang Daoyu, 2013).

In terms of external motivation, the current CBI reform places college English teachers in the new curriculum system. Teachers can find new position in the reform only through conforming to the trend and striving to develop professional quality. According to the investigation of Feng Yan, "with the improvement of basic educational level, public foreign language course in universities especially in key universities 
has lost the reason of existence" (Feng Yan, 2010). Liu Runqing also "predicts within several years, the direction of career development of college English teachers is ESP (Liu Runqing, 2010). Qin Xiubai once pointed out, "From the long run perspective, the main stream of English education in universities of our country should be ESP teaching" (Qin Xiubai, 2003). In view of this, huge stress brought by ESP course no doubt will be strong motivation to stimulate college English teachers to speed up professional development and transformation.

Besides, many ESP teachers in the transformation have internally realized potential opportunity contained in the reform and have strong will to participate in it. They consciously change teaching methods and ideas. On one hand, they unceasingly improve the ability to use English to teach. On the other hand, they make the best of resources to enrich professional knowledge involved in CBI. They can take advantage of effective ways to actively change from EGP teachers to ESP teachers. The author once made survey about the will of some teachers to change from EGP to ESP. The result shows although $85 \%$ of teachers think ESP curriculum indeed brings huge occupational stress for them, $82.4 \%$ of teachers think the stress can drive their professional development. $81.7 \%$ of teachers choose to actively face the current reform instead of accepting passively.

\section{The Road to ESP Teachers' Professional Development in the Transformation Stage}

According to the research, ESP teachers' professional quality needs to improve substantially and the cycle of improvement is long. Therefore, the promotion of ESP teachers' professional quality development through many ways concerns the progress and result of college English teaching reform. The author thinks we can explore the road to ESP teachers' professional development in the transformation stage from the following eight aspects.

1) Action research and reflective teaching -independent development: College English reform will definitely bring confusions and difficulties for teachers. The self action research in reflective teaching is no doubt the preferred way to solve the dilemma and seek benign professional development. Teachers' action research means educators find out the solution to problems faced in teaching practice on the basis of systematic reflection and exploration (Zhi Yongbi, 2011). It is a new way of teachers' independent development that can let teachers change passive development into active growth.

However, the research on teachers' action can be realized by integrating in reflective teaching practice in daily life. Teachers' reflection means they think about teaching activities and continuously reflect teaching practice, opinions on education, teaching behavior and effect, affirm or deny, strengthen or amend the behavior through effective review, diagnose and self-monitoring and optimize the behavior in the dynamic professional development. The contents include the reflection on teaching idea, reflection on the role of teacher, reflection on professional knowledge of their own and the reflection on organization and implementation of teaching (Yong Xiang, 2010).

With the help of reflection, teachers can keep the pursuit for professional knowledge and be highly sensitive to professional development, continuously find and learn new things as well as gain new experience in setback and success and conclude teaching practice. Therefore, Wallace (1998) showed teachers' professional development in Fig.1, namely the continuous cyclic development of teaching practice and reflection; Pollard (2001) used Fig.2 to show intimate connection and mutual promotion of teachers' professional development and reflective teaching and Fig.3 to show the relation between reflective teaching and action research (quoted from Wang Qiang, 2002).

It shows the process of reflective teaching means action research. Teachers carry out multi-level and multi-angle analysis and reflection of teaching practice, learn to teach in the cyclic teaching progress and continuously optimize and develop in teaching practice. In order to realize benign professional development of ESP teachers, action research in the reflective teaching practice is the inevitable and primary way.

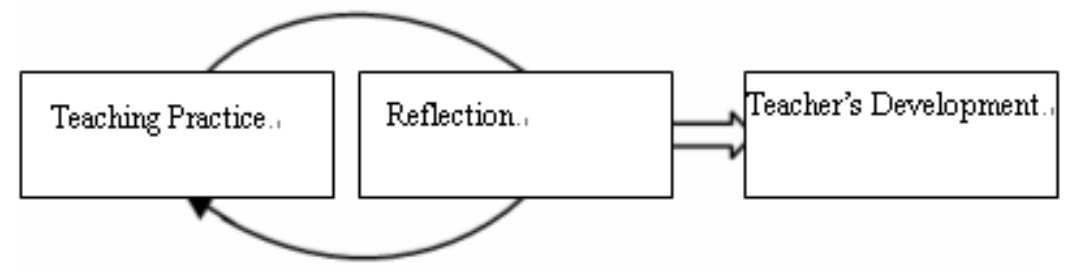

Fig. 1. Cyclic reflection mode

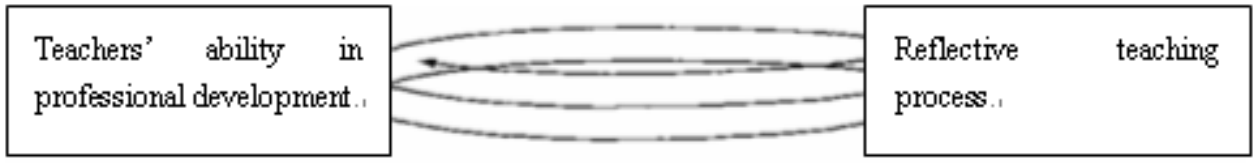

Fig. 2. Teachers' professional development 


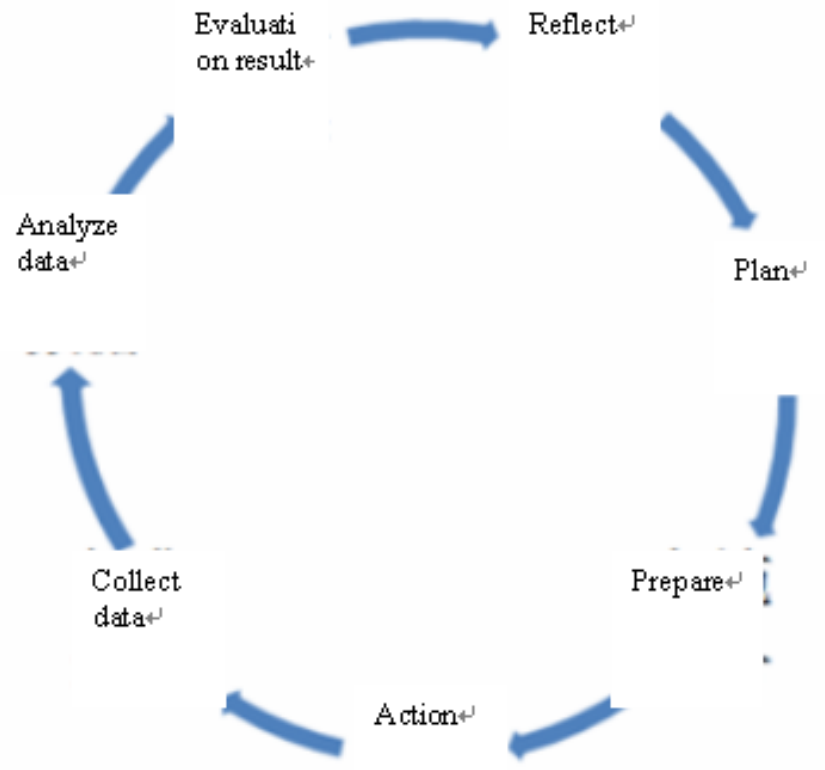

Fig. 3. Reflective thinking

2) Mutual aid team of the same subject - team development: In professional development, individual action research sometimes seems very hard. Teachers should reflect in the mutual aid team of the same subject. The mutual aid team of the same subject refers to the teaching research team with comprehensive, constant and active cooperation and mutual improvement through interaction of teachers of the same subject, with the aim of teachers' professional development. In this team, teachers can research typical lessons together, share experience and carry out collective reflection and action research on the common problems in teaching, explore the source and solution of the problems. The research on problems will be deeper, the solution will be more comprehensive and the speed will be faster.

The biggest advantage of mutual aid team of the same subject is that it can cover the shortage of individual ability, effectively form resultant force of teachers and let them gain experience that cannot be acquired in independent reflection. Therefore, mutual aid team of the same subject is an efficient way of win-win cooperation to promote professional development of teachers.

3) Virtual community - assistant development: Generally speaking, the reflection research of mutual aid team of the same subject must be conducted in the office. But now most teachers have smart mobile phone and network, the function of which is increasingly stronger and the speed is faster. Besides, more and more communication software makes the communication between teachers more convenient, such as QQ group, Wechat group, microblog, Momo, YY, Fetion and cyber space. ESP teachers can organize all types of virtual communities through these ways, exchange information and research and discuss problems whenever and wherever possible. Predictably, virtual community will definitely become important supplementary means of college teachers' professional development and the new way for teachers to contact, learn and cooperate beyond time and space limit.

4) Help of professional teachers - assist in the development: Except for mutual cooperation of ESP teachers, the help of professional teachers is also important link to accelerate the development. ESP curriculum makes the distance between college English teachers and professional teachers closer and makes them have common ground and interests in teaching contents, methods even ideas. The new type relation between teachers becomes new impetus for ESP teachers' development. ESP teachers should make the best of advantages of professional teachers and actively cooperate with them and ask them for help to solve problems in ESP curriculum and speed up the professional development.

5) Participate in the professional practice - boost the development: For ESP courses with strong practicality, such as Business English and Travel English, ESP teachers may as well actively participate in practice of students in these majors and some scientific research tasks of professional teachers and integrate it in professional disciplines to help the professional development instead of only regarding themselves as college English teachers.

6) Centralized training - scale development: In the transformation from college English teachers to ESP teachers, it may be impossible to get the ideal development effect or balanced development only by relying on individuals or small teams. Therefore, the help from schools is also indispensable. As local undergraduate university, we are inferior to " 211 " and "985" universities. In terms of subject reform, we lack cuttingedge idea and often blindly follow the first-class universities. For this reason, we can use "bring in" and "walk out" to narrow the gap with the top universities. "Bring in" means continuously inviting professors that have made brilliant 
achievements in CBI reform or unique characteristics to give lectures or train us, making all ESP teachers have the opportunity to listen to opinions and suggestions of experts; "walk out" means sending college English teachers of our school to top universities with CBI reform to attend class, exchange and consult to accelerate our professional development with the help of teaching and research results of others.

7) Actively carry out teaching research - lead the development: As ESP teachers in the transformation period, we should reflect and research new textbooks and class and explore aspects involved in the current reform, such as the change of roles between teachers and students, change of psychology of teachers and students, change of teaching strategies, change of learning strategies, teaching effect evaluation, learning effect evaluation and the difference between ESP teaching and college English teaching. Therefore, ESP teachers should actively carry out related teaching research and guide professional development from the perspectives of reason and theory.

8) Support of school policy - stimulate the development: The stress of ESP teachers rises obviously on preparation of lesson, having class and scientific research, so it is inevitably for teachers to complain. Besides, many teachers lose the sense of achievement in teaching because of the difficulties in ESP curriculum and then they have the sense of anxiety and crisis. It influences their enthusiasm and gumption. In view of this, schools should have corresponding policy or proper evaluation mechanism to support, encourage even reward college English teachers to consciously walk the road of ESP transformation and actively devote to the professional development.

\section{CONCLUSION}

ESP curriculum provision under CBI teaching model is the inevitable outcome of college English reform and conforms to long-term plan of national education development. It brings huge occupational stress for ESP teachers in the transformation period and provides impetus for professional development of them in the future. In face of reform, ESP teachers should take measures at the same time and work hard to speed up professional development of them. Only in this way can they perfectly transform from college English teachers to ESP teachers as soon as possible. However, just as Wu Yian (2008) said, the professional development of teachers is a "long-term, dynamic, practical and environment-based" process. In view of this, the author thinks teachers and school can make concerted effort to drive comprehensive development of professional literacy of ESP teachers at least through eight ways.

\section{REFERENCES}

[1] The State Council. Outline of the National Medium and Long Term Educational Reform and Development Plan (2010-2020), Beijing: China Legal Publishing House, 2010:24

[2] Department of Higher Education of the Ministry of Education. Requirements of College English Teaching Course, Beijing: Foreign Language Teaching and Research Press, 2007:6

[3] Mohan B. A. Language and Content [M]. Reading, MA: AddisonWesley, 1986:54.
[4] Krahnke K. Approaches to Syllabus Design for Foreign Language Teaching[M]. New York: Prentice Hall, 1987:135.

[5] Cai Jigang. Research on Compiling Concept of College English Textbooks [J], Foreign Language Research, 2011(5):10

[6] Lei Chunlin. The Content-based Instruction and Compound Foreign Language Professional Teaching-Take Teaching Mode of Business English as an Example $[\mathrm{J}]$, Computer-assisted Foreign Language Education, 2006(6):32-38

[7] Yuan Pinghua. College English Curriculum Reform and Language Teaching Mode Depending on Subject Content [J], Foreign Language World, 2010(3):7-13

[8] Liu Runqing. Use Content to Drive Language Teaching [R], the Second Annual Meeting Lecture Paper of Chinese Pedagogical Linguistics, Xi'an, Shaanxi, 2011,5

[9] Sun Youzhong, Li Liwen. CBI and ESP and English Major of University in China and the Direction of College English Teaching Reform [J], Foreign Language Research, 2011(5):1-4

[10] Cai Jigang. Research Foreign Language Teaching on the Basis of College ESP Course Pattern of Requirement Analysis [J], Foreign Language Teaching, 2012(3):48

[11] Yang Daoyun. Discussion on Professional Ability of Teachers with Double Degree of English Major Based on CBI [J], China Adult Education, 2012(13):65-66

[12] Zhao Xiuyan. Research on Practice Effect of Course System Reform of Content-based Instruction in English Majors at Fundamental Stage [J], Foreign Languages and Their Teaching, 2014(1):47-53

[13] Cai Jigang. From General English to English for Academic Purposes Return to College English Teaching [J], Foreign Language and Their Teaching, 2014(1):9-14

[14] Xia Yang. Research on Demonstration of Knowledge Grasped by Foreign Language Teachers and Their Psychology under the Background of CBI Curriculum Reform [J], Modern Foreign Languages 2012(11):23-37

[15] Pawan, F. \& B. Sietman. Helping English Language Learners Succeed in Middle and High Schools[M]. Alexandria, VA: TESOL. 2007:44.

[16] [16]Zhou Yueliang. Professional Development of Teachers in the Information Environment [M], Beijing: Science Press, 2008:4

[17] Yang Daoyu, Mi Xiao. Research on Dynamic Mechanism of Professional Development of Teachers [J], Educational Review, 2013(6):45-47

[18] Feng Yan.Get Rid of English: Inevitable Choice of the Development of Public Foreign Language Teachers in Key University [J], University Education Science, 2010(3):67-72

[19] Qin Xiubai. Property, Category and Teaching Principles of ESP [J], Journal of South China University of Technology, 2003(4):79-83

[20] Zhi Yongbi, Wang Yongxiang. Research on Foreign Language Teaching Action and Professional Development of Teachers [M], Suzhou: Suzhou University Press, 2011:6

[21] Yong Xiang. How Do Teachers to Reflect and Research [M], Shenyang: Liaoning University Press, 2010:86-253

[22] Wang Qiang. Research on Action of English Teachers [M], Beijing: Foreign Language Teaching and Research Press, 2002:14

[23] Wu Yian. Exploration on Professional Development of Foreign Language Teachers [M], Foreign Language Research, 2008(3):29-38 